6. Muzyka O.O., Shaiuk A.V. Osoblyvosti zastosuvannia metoduku "Profil laterantnoi organizatsii mozku" v roboti psychologa [Features of the application of the method. Profile of the lateral brain organization]. Praktuchna psukhologiia ta sotsialna robota. 2014. № 5 (182). s.72-76. [in Russian].

7. Palii A.A. Dyferentsialna psykhologiia [Diffental psychology] - Kyiv, Akademvydav, 2010 - 429 s. [in Russian].

8. Rukovodstvo po funktsionalnoi mezhpolusharnoi asimmetrii [Funktional hemisphere asymmetry guide] / Otv.red.V.F.Fokin, Moskva: Nauchnyi mir, 2009 - 836 s. [in Russian].

9. Semenovich A.V. Vvedeniie v neiropsikhologiyu detskogo vozrasta.[Introduction to neuropsychology of childhood] Moskva: Genezis, 2018 - 268 s. [in Russian].

10. Semenovich A.V. Neiropsikhologicheskaia korrektsiia v detskom vozraste .[Neuropsychological correction of childhood] Moskva: Genezis, 2018 - 474 s. [in Russian].

11. Khomskaia Ye.D. Neiropsikhologiia: uchebnik dlia vuzov. 3-ie izdaniie. [Neuropsychology: textbook for higher education] Sankt-Peterburg: Piter, $2019-767$ s. [in Russian].

12. Khomskaia Ye.D., Yefimova I.V., Budyka Ye.V. i dr. Neiropsikhologiia individualnych razlichii: uchebnoie posobiie [Neuropsychology of individual differences] Moskva: Rossiiskoie pedagogicheskoie agenstvo, 1997 - 281 s. [in Russian].

\title{
Hrechukha $V . H$. The role of lateralization of brain functions in the adaptation of the child to schooling
}

In the article are raised the theoretical questions of formation of cerebral hemispheres interaction and lateralization of functions of a brain in a child, taking into account, which, in the author's opinion, is one of the conditions for effective adaptation of younger students to school. It is emphasized, that in the neuropsychology of childhood the analysis of the formation of cerebral hemispheres interaction is one of the priority directions and accentuates the importance of processes of cerebral hemispheres interaction for cerebral organization of specific human forms of adaptive behavior. The three main levels of organization of interhemispheric interactions in ontogeny are considered. In the first stage (from pre-natal development to 2-3 years the basic is laid for interhemispheric provision of neurophysiological, neurohumoral and neurochemical asymmetries, which underlie the somatic, affective and cognitive status of the child. At this level for the first time express yourself the profound neurobiological preconditions for the future psycho-physiological style of the child's behavior. In the second stage from 3 to 7 years the interhypocamping commissural systems are activated, all major asymmetries of the operating level are fixed and automated, the dominance of brain hemispheres by hand and language is formed, the right and left-sided hemispherical locus of control over updating of cognitive (verbal and non-verbal) and emotional psychological factors and functions are fixed. At the third stage, from 7 to 12-15 years the morphological and functional maturation of the corpus callosum, which provides the interhemispherical organization of mental processes at the most important level for social adaptation is completed. Therefore, it is the degree of the well formed interhemispherical interaction, that allows the child not only to build their own behavioral programs, to set clearly defined goals, but also to control (adjust) them in accordance with the requirements of the natural environment and society.

The author emphasizes the necessity of carrying out timely neuropshychological diagnostics of disorders of the interhemispherical organization of mental prozesses, which will allow to find effective ways to successful adaptation of the child to schooling.

Key words: cerebral hemispheres brain interaction, lateralization of brain functions, adaptation of the child to schooling.

УДК 378.011.3-051:81’243

DOI https://doi.org/10.31392/NPU-nc.series5.2020.73-1.17

Гулич М. М.

\section{ФОРМУВАННЯ ПОЛІКУЛЬТУРНОЇ КОМПЕТЕНТНОСТІ МАЙБУТНІХ УЧИТЕЛІВ ІНОЗЕМНОЇ МОВИ В ПРОЦЕСІ ПРОФЕСІЙНОЇ ПІДГОТОВКИ: СУТНІСТЬ ПОНЯТТЯ}

Необхідність формування полікультурної компетентності як невід’ємного складника професійної компетентності майбутніх фахівців важко переоцінити в умовах сучасного полікультурного суспільства. Особлива увага приділяється полікультурній компетентності вчителів іноземної мови, оскільки в них є унікальна можливість повноцінно реалізувати свою полікультурну особистість у процесі професійної підготовки.

Основоположними чинниками, щзо зумовлюють необхідність негайного розв'язання окресленої наукової проблеми в контексті сучасної освітньої парадигми, є сочіальне замовлення украӥнського суспільства на вчителів-професіоналів, здатних ефективно взаємодіяти в умовах полікультурного середовища, відсутність системної професійної підготовки майбутніх фахівців, брак наукових праць з теорії та практики формування полікультурної компетентності майбутніх учителів як невід 'ємного складника їхньої професійної компетентності.

Здійснено теоретичний аналіз і детермінацію понять “компетенція”, “компетентність ” $i$ “полікультурна компетентність” як споріднених педагогічних категорій. Констатовано, щчо, незважаючи на значну кількість досліджень, присвячених вивченню змісту поняття "полікультурна компетентність", у науково-педагогічній літературі спостерігається неоднозначність трактування цьвого терміна, ототожнення з іншими поняттями. Підкреслено, щзо сучасна педагогічна наука полікультурну компетентність трактує як інтегративну особистісно-професійну якість майбутнього фахівия, щзо забезпечує його здатність здійснювати міжкультурну та міжетнічну взаємодію в модернізованих умовах глобалізованого простору. Подано авторське визначення означеного терміна: полікультурна компетентність майбутнього вчителя іноземної мови - це складне інтегроване поняття, щэо відтворює здатність особистості не 
лише популяризувати власну культурну спадщину, а й бути готовим до продуктивної інтеракиії в умовах полікультурного середовища на засадах діалогу культур, взаєморозуміння, взаємоповаги й толерантного ставлення до иіннісних надбань інших національностей.

Запропоновано використання різноманітних інтерактивних технологій для формування відповідного рівня полікультурної компетентності майбутніх учителів іноземної мови.

Ключові слова: якість освіти, компетениія, компетентність, полікультурна компетентність, компетентнісний підхід, професійна підготовка, вищий навчальний заклад, майбутні вчителі іноземної мови.

Сучасна освіта України переживає модернізацію, зумовлену глобалізацією освітнього простору, входженням України до світового та європейського співтовариства, упровадженням кардинально відмінних від попередніх стандартів нової української освіти. Фундаментом новітніх тенденцій у процесі фахової підготовки педагогів стає компетентнісний підхід, що довів свою ефективність у багатьох європейських країнах. У Концепції Нової української школи зазначається, що “суттєвих змін зазнає процес і зміст підготовки вчителя, оскільки педагог виконуватиме роль не тільки наставника та джерела знань, а коуча, фасилітатора, тьютора, модератора в індивідуальній освітній траєкторії дитини" [6].

Це означає, що сучасній українській освіті вкрай потрібні фахівці з високим рівнем професійної компетентності, професійного інтелекту, самоосвіти й готовності до неперервного навчання впродовж життя.

У наукових працях Н. Бібік, С. Гончаренка, О. Дубасенюк, О. Пометун, Н. Ничкало, О. Савченко, А. Хуторського детально висвітлено розуміння компетентності як складної системи. Поняття "професійна компетентність” стало об’єктом наукових розвідок І. Зимньої, І. Зязюна, Н. Кузьміної, Н. Ничкало, С. Сисоєвої, В. Сластьоніна й інших

Аналіз різних підходів до визначення сутності поняття полікультурності, полікультурної освіти та полікультурної компетентності розкрито в працях багатьох вітчизняних дослідників (І. Бахов, Л. Гончаренко, О. Котенко, В. Кузьменко, М. Моцар, Л. Перетяга, Л. Султанова, Н. Ткачової, А. Чередниченко).

Але, попри наявні теоретико-методичні розвідки, зауважимо, що виокремлені наукові дослідження стосуються лише деяких аспектів, але не окреслюють цілісної картини даної наукової категорії. Отже, постає актуальна потреба опрацювання та узагальнення результатів наукових розвідок учених у цій царині.

Метою статті є здійснити теоретичний аналіз і детермінацію поняття полікультурної компетентності майбутнього фахівця в науковому дискурсі.

Відповідний рівень полікультурної компетентності майбутніх фахівців - один із основних стандартів сучасної вищої освіти та якісний показник пріоритетності вищого навчального закладу в освітньому й науковому просторі.

Необхідність здійснення навчання та виховання української молоді на засадах полікультурності розглядається в низці нормативно-правових документів (Конституція України, Закон України “Про вищу освіту”, Концепція громадянського виховання, Концепція національно-патріотичного виховання дітей і молоді, Концепція Нової української школи тощо). Законодавчо-правова база слугує цільовим вектором для імплементації ідей полікультурної освіти в процес фахової підготовки студентів у вищих навчальних закладах.

Оскільки педагог є ключовою фігурою та ретранслятором якісного змісту освіти, а також еталоном у формуванні базових компетентностей вихованців, то, без сумніву, майбутній учитель сам зобов'язаний бути полікультурною особистістю з непересічним світоглядом і способом критичного аналізу безмежного потоку інформації, а також подачі саме того контенту, який видається відповідним у руслі ідей нової освітньої парадигми. Тобто педагог НУШ, зокрема вчитель іноземної мови, покликаний бути новатором, дослідником із мотиваційною орієнтацію на професійний розвиток і самопізнання. Беззаперечним чинником у становленні фахівця нової генерації є освіта та якість освіти.

Поняття “якість освіти” дуже багатозначне за змістом та інтегрує якість національної доктрини освіти, якість управління освітою, якість умов забезпечення освіти, якість процесу навчання, якість результатів навчання. Сьогодні якість освіти аналізується на різних рівнях функціонування: державному (інформаційне забезпечення сталого розвитку національної системи освіти), регіональному (оцінювання ефективності територіальних систем освіти), муніципальному, локальному та індивідуальному [7].

Індикаторами якості освіти й ефективності навчального процесу як в Україні, так і в інших європейських країнах стали компетентності, що визначають готовність майбутніх фахівців до професійної діяльності.

Аналіз наукових розвідок засвідчує, що компетентнісний підхід у здійсненні підготовки майбутніх учителів іноземної мови є одним із визначальних, оскільки передбачає формування змісту освіти, виходячи із запрограмованих результатів навчання, розроблення чітких критеріїв для оцінювання результатів навчання студентів на різних етапах і в різних формах їхньої підготовки [1].

Істотно важливим для нашої роботи є опрацювання категоріально-поняттєвого апарату дослідження, а саме таких понять, як компетенція, компетентність і полікультурна компетентність, оскільки існують різні трактування зазначених категорій.

У процесі дослідження ми базувалися на наявних у науці трактуваннях поняття компетентності: компетентність - це знання, уміння, навички та досвід, які формують професійні властивості фахівця на достатньому рівні для якісного виконання ним професійних функцій [2, с. 354]. Компетентність виявляється як 
особистісно усвідомлена система знань, умінь, навичок, що має універсальне значення й може бути використана в різних видах педагогічної діяльності. Академік НАН України О. Савченко, посилаючись на ключові компетентності, прийняті Радою Свропи, називає ті, які безпосередньо стосуються вміння вчитися: компетентності, пов'язані з інформатизацією суспільства. Володіння цими технологіями, розуміння в їх використанні слабких і сильних аспектів, способи критичних суджень у ставленні до інформації, що розповсюджується масмедійними засобами; здатність учитися протягом життя як основа неперервного навчання в контексті як особистісного професійного, так і соціального розвитку [11, с. 82-95].

Однак принциповим у контексті дослідження є чітке розмежування понять “компетенція” та “компетентність”. У цьому аспекті заслуговують на увагу наукові висновки С. Сисоєвої. Дослідниця доводить, що обидва терміни хоча й взаємопов'язані, проте несуть цілком відмінне смислове навантаження. Так, зокрема, компетенція, трактується як “визначена норма стосовно неперервної освіти, яка задається освітніми стандартами й використовується для формування вимог до результатів навчання”. На противагу цьому, компетентність, як влучно зауважує авторка, є “інтегрованою особистісною якістю людини (іiі капіталом), що формується на етапі навчання, остаточно оформлюється й розвивається в процесі практичної діяльності та забезпечує компетентний підхід до вирішення професійних завдань” [12].

Розглянемо детальніше погляди вчених щодо трактування поняття “полікультурна компетентність". У науковій літературі існують численні тлумачення цього терміна, які суттєво не відрізняються, а лише акцентують увагу на різних аспектах цієї категорії. Окрім цього, поняття "полікультурна компетентність" часто ототожнюється 3 такими дефініціями, як “міжкультурна компетентність”, “мультикультурна компетентність”, “кроскультурна компетентність”, “інтеркультурна компетентність” тощо.

Так, у працях багатьох вітчизняних дослідників полікультурність розглядається як здатність інтегруватися в іншу культуру за збереження взаємозв'язку з рідною мовою, культурою, грунтується на поєднанні особистісних якостей, синтезованих знаннях, уміннях, навичках позитивної міжетнічної й міжкультурної взаємодії, що сприяє безконфліктній інтеграції до полікультурного освітнього простору вищого навчального закладу.

Отже, акцент ставиться на інтеркультурності сприйняття, запереченні акомодації чи нівеляції власної культури, розумінні власної ідентичності й забезпеченні повноцінного діалогу культур. Саме такий алгоритм здійснення полікультурної освіти й виховання у вищій школі є прийнятним у межах дослідження.

Цінними для дослідження є також наукові позиції Л. Чередниченко. Дослідниця трактує полікультурну компетентність як показник сформованості комплексу професійних знань, умінь, навичок, які визначають готовність до успішного виконання педагогічної діяльності, здатність особистості кваліфіковано вирішувати завдання. Отже, науковиця зауважує, що це поняття включає сукупність інтегрованих якостей і ціннісних орієнтацій, що забезпечують високу результативність праці. Структурними компонентами полікультурної компетентності, згідно з Л. Чередниченко, є мотиваційно-ціннісний, пізнавально-операційний, особистіснорефлексивний [15].

Поряд із цим М. Моцар уважає, що полікультурна компетентність майбутніх фахівців - це єдність мотиваційно-ціннісного, лінгвокраїнознавчого, афективного та конативного компонентів [8].

Натомість С. Вітвицька переконана, що полікультурна компетентність включає когнітивний, операційнодіяльнісний та особистісний компоненти [3].

Л. Перетяга вбачає сутність полікультурної компетентності в тому, що особистість, яка володіє цією компетентністю, є активним носієм досвіду в галузі міжособистісної взаємодії з представниками різних культур [14].

Л. Гончаренко доречно зауважує, що полікультурна компетентність педагога - це не лише здатність до життєдіяльності в багатокультурному середовищі, а ще й теоретична та практична готовність до здійснення професійної діяльності в такому суспільстві. Науковці не безпідставно стверджують, що цей феномен грунтується на поєднанні синтезованих знань з полікультурності, умінь використовувати свої знання на практиці та професійно значущих особистісних якостях [4].

Наведене формулювання фокусує увагу на тому, що визначені складники не протиставляються один одному, а відображають полісемантичність дефініції, що розглядається, а також сприяють більш повному його розумінню.

Вдале, на наш погляд, визначення вищезгаданого поняття подає також Н. Ткачова. На думку дослідниці, полікультурна компетентність є особистісним утворенням, що об'єднує в собі відповідні знання, уміння, якості, цінності. Саме ці компоненти, як зауважує авторка, забезпечують здатність людини успішно взаємодіяти з носіями інших культур на основі прояву толерантності та взаємоповаги, готовність докладати активні зусилля для розвитку розмаїття форм культурного самовираження в сучасному глобалізованому суспільстві [13].

Отже, загалом у науковій літературі поняття “полікультурна компетентність педагога” визначається як інтегративна особистісно-професійна якість особистості майбутнього фахівця, що забезпечує його здатність здійснювати міжкультурну та міжетнічну взаємодію в модернізованих умовах глобалізованого простору.

Аналіз наукової досліджень у цій галузі дав нам змогу проаналізувати досвід вітчизняних і зарубіжних науковців щодо тлумачення поняття “полікультурна компетентність майбутнього фахівця” та запропонувати 
власне визначення. Ми дійшли висновку, що полікультурна компетентність майбутнього вчителя іноземної мови - це складне інтегроване поняття, що відтворює здатність особистості не лише популяризувати власну культурну спадщину, а й бути готовим до продуктивної інтеракції в умовах полікультурного середовища на засадах діалогу культур, взаєморозуміння, взаємоповаги й толерантного ставлення до ціннісних надбань інших національностей.

Оскільки феномен полікультурності - складне інтегративне утворення, нам видається логічним, що для формування полікультурної компетентності студентів потрібні цілеспрямовані та комплексні заходи, які мають здійснюватися протягом усього терміну навчання у вищому навчальному закладі. Отже, освітній процес української вищої школи, де готують майбутніх фахівців, усе ще залишається конвенційним і неповністю відповідає критеріям, необхідним для розвитку полікультурної компетентності студентів.

Оскільки взаємозалежний зв'язок мови та культури є константним і безапеляційним, то пізнання й розуміння культурних реалій іншого народу через вивчення його мови може бути, на наш погляд, цілком раціональним та успішним.

Уважаємо за доцільне зауважити, що вагомим, на наш погляд, чинником у цьому ракурсі є впровадження в систему професійної підготовки студентів інтерактивних технологій з акцентом на країнознавчому компоненті. Міні-доповіді, дискусії, рольові та ділові ігри, тренінги, веб-квести, участь у проєктній діяльності, а також використання онлайн-ресурсів для інтернет-комунікації в навчальному процесі можуть стати дієвим механізмом у формуванні полікультурної компетентності майбутніх учителів іноземної мови. Ці нескладні кроки, на наше переконання, уможливлять реалізацію в освітньому процесі діалогу культур як одного зі шляхів формування полікультурної компетентності майбутніх фахівців.

Висновки. Підсумовуючи викладене вище, зазначимо, що полікультурна компетентність майбутнього вчителя іноземної мови є невід'ємним складником його професійної компетентності. Це продиктовано сучасними тенденціями в розвитку української освіти, оскільки першочерговою для майбутнього фахівця є необхідність здійснювати свою професійну діяльність в умовах поліфонічного середовища.

Формування полікультурної компетентності в процесі професійної підготовки майбутніх учителів іноземної мови сприятиме створенню сприятливої атмосфери в освітньому процесі, появі в студентів готовності та здатності до самоосвіти, творчої самореалізації та самоствердження.

Доцільним і перспективним може бути вивчення педагогічних умов і шляхів формування полікультурної компетентності студентів вищих навчальних педагогічних закладів.

\section{Використана література:}

1. Бахов I. С. Формування професійної міжкультурної компетентності майбутніх перекладачів у вищому навчальному закладі : дис. ... канд. пед. наук : 13.00.04. Київ, 2011. 254 с.

2. Вища освіта України і Болонський процес / за ред. В. Г. Кременя. Тернопіль : Навчальна книга - Богдан, 2004. 384 с.

3. Вітвицька С. С. Формування полікультурної компетентності магістрів освіти у процесі вивчення педагогіки вищої школи. Проблеми освіти : збірник наукових праць. Вип. 82. Вінниця-Київ, 2015. С. 42-45.

4. Гончаренко Л. А. Полікультурна освіченість педагога: теорія і практика : монографія. Херсон : РІПО, 2009. 136 с.

5. Зимняя И. А. Ключевые компетентности как результативно-целевая основа компетентностного подхода в образовании. Авторская версия. Москва : Исследовательский центр проблем качества подготовки специалистов, 2004. С. $22-23$.

6. Концепція Нової української школи. URL: https:// www.kmu.gov.ua /.../ukrainska-shkola-compressed.pd.

7. Кремінь В. Г. Модернізація системи вищої освіти : соціальна цінність і вартість для України : монографія / за ред. В. Г. Кременя. Київ : Педагогічна думка, 2007. 257 с.

8. Моцар М. М. Формування полікультурної компетентності майбутніх перекладачів з використанням технологій дистанційного навчання : дис. ... канд. пед. наук : 13.00.04. Київ, 2018. 242 с.

9. Педагогічна майстерність : підручник / І. А. Зязюн та ін. ; за ред. І. А. Зязюна. Київ : Вища школа, 1997. 349 с.

10. Хомич Л. О., Султанова Л. Ю., Шахрай Т. О. Полікультурна освіта в контексті загальнокультурного розвитку особистості педагога : монографія. Кіровоград : Імекс-ЛТД, 2014. 212 с.

11. Савченко О. Я. Уміння вчитися як ключова компетентність шкільної освіти. Педагогічна і психологічна наука в Україні : збірник наукових праць. Київ : Педагогічна думка, 2007. Т. 2. С. 82-95.

12. Сисоєва С. О. Дискусійні аспекти наукового тезаурусу нового Закону України “Про вищу освіту”. Неперервна професійна освіта: теорія і практика. 2015. Вип. 1-2. С. 7-14.

13. Ткачова Н. О. Нормативно-правова база для формування полікультурної компетентності студентів в університетах. Науковий вісник Ужгородського національного університету. Серія "Педагогіка. Соиіальна робота". Ужгород : Говерла, 2019. Вип. 2 (45). С. 196-199.

14. Перетяга Л. Є. Дидактичні умови формування полікультурної компетентності молодших школярів : дис. ... докт. пед. наук : 13.00.04. Харків, 2008. 175 с.

15. Чередниченко Л. А. Формування полікультурної компетентності майбутнього вчителя у процесі професійної підготовки : автореф. дис. ... канд. пед. наук : 13.00.04. Харків, 2012. 20 с.

\section{References:}

1. Bakhov I. S. (2011) Formuvannia profesiinoi mizhkulturnoi kompetentnosti maibutnikh perekladachiv u vyshchomu navchalnomu zakladi [Formation of professional multicultural competence of translators in higher educational institutions] Candidate's thesis [in Ukrainian].

2. Vitvytska S.S. Formuvannia polikulturnoi kompetentnosti mahistriv osvity u protsesi vyvchennia pedahohiky vyshchoi shkoly. Problemy osvity : Zbirnyk naukovykh prats. Vyp. 82. Vinnytsia-Kyiv, 2015. S. 42-45. 
3. Vyshcha osvita Ukrainy i Bolonskyi protses (2004) [Higher education in Ukraine and Bolon process]. Ternopil : Navchalna knyha - Bohdan [in Ukrainian].

4. Honcharenko L. A. Polikulturna osvichenist pedahoha: teoriia i praktyka [Multicultural education of pedagogue: theory and practice]. Kherson: RIPO [in Ukrainian].

5. Zymniaia Y. A. Kliuchevыe kompetentnosty kak rezultatyvno-tselevaia osnova kompetentnostnoho podkhoda $\mathrm{v}$ obrazovanyy. Avtorskaia versyia. / Y. A. Zymniaia. - M.: Yssledovatelskyi tsentr problem kachestva podhotovky spetsyalystov, 2004. 22-23 [in Russian].

6. Kontseptsiia Novoi ukrainskoi shkoly [Elektronnyi resurs] - Rezhym dostupu:https:// www.kmu.gov.ua /.../ukrainska-shkolacompressed.pd.

7. Kremen V.H. (2007). Modernizatsiia systemy vyshchoi osvity : sotsialna tsinnist i vartist dlia Ukrainy : monohrafiia / za red. V. H. Kremenia. - Kyiv : Pedahohichna dumka. 257 s.

8. Motsar, M. M. (2018). Formuvannia polikulturnoi kompetentnosti maibutnikh perekladachiv z vykorystanniam tekhnolohii dystantsiinoho navchannia [Formation of Multicultural Competence of Future Translators Using Distance Learning Technologies]. Candidate's thesis [in Ukrainian].

9. I. A. Ziaziun, L. V. Kramushchenko, I. F. Kryvonos ta in. Pedahohichna maisternist [Pedagogical skill]; za red. I. A. Ziaziuna (1997). K. : Vyshcha shkola [in Ukrainian].

10. L. O. Khomych, L. Yu. Sultanova, T. O. Shakhrai (2014). Polikulturna osvita v konteksti zahalnokulturnoho rozvytku osobystosti pedahoha. [ Multicultural education in the context of ]Kirovohrad: Imeks-LTD. 212 p. [in Ukrainian].

11. Savchenko O. (2007). Uminnia vchytysia yak kliuchova kompetentnist shkilnoi osvity [The of studying as the key competence of the school education] Pedahohichna i psykholohichna nauky v Ukraini - K. : Pedahohichna dumka.- T. $2 .-$ pp. 82 - 95 [in Ukrainian].

12. Sysoieva S. O. (2015). Dyskusiini aspekty naukovoho tezaurusu novoho Zakonu Ukrainy "Pro vyshchu osvitu" [ Discussion aspects of the science thesaurus of the new law of Ukraine "On higher education"]. Neperervna profesiina osvita: teoriia $i$ praktyka - Continuing professional education: theory and practice. 1-2. 7-14. - Rezhym dostupu: http://nbuv.gov.ua/UJRN/ NPO 2015 1-2_3 [in Ukrainian].

13. Tkach̆ova $\overline{\mathrm{N}}$. O. Normatyvno-pravova baza dlia formuvannia polikulturnoi kompetentnosti studentiv v universytetakh. [Rules and regulations for the formation of polycultural competence in University students in China]. Naukovyi visnyk Uzhhorodskoho natsionalnoho universytetu : seriia: Pedahohika. Sotsialna robota. Uzhhorod : Hoverla. 2 (45). 196-199 [in Ukrainian].

14. Peretiaha L. (2008). Dydaktychni umovy formuvannia polikulturnoi kompetentnosti molodshykh shkoliariv - Kharkiv. - 175 p. [in Ukrainian].

15. Cherednychenko L.A. Formuvannia polikulturnoi kompetentnosti maibutnoho vchytelia u protsesi profesiinoi pidhotovky [Formation of multicultural competence]. Extended abstract of candidate's thesis. 20 p. [in Ukrainian].

\section{Hulych M. M. Formation of foreign language teachers' polycultural competence in the process of professional training}

The necessity of the development of polycultural competence as an important component of the professional competence of the future specialists is highly appreciated in the modern multicultural society. Special attention is given to polycultural competence of the English language teachers, as they have a unique opportunity to fully realize their polycultural personality in the process of studying foreign languages.

The basic factors determining the necessity for immediate solution of the given scientific problem in the context of the modern educational paradigm is the social order of the Ukrainian society for the professional teachers, able to effectively interact in the multicultural environment, the absence of systematic professional training, the lack of the scientific researches devoted to the problem of future teachers' polycultural competence formation as an integral part of their professional competence.

Theoretical analysis and determination of the concepts of "competence", "competence" and "polycultural competence" as related pedagogical categories are carried out. It is stated that, despite the considerable amount of scientific researches devoted to the investigation of the content of the concept of "polycultural competence", there is ambiguity in the interpretation of this term and its identification with other concepts in the pedagogical literature. It is emphasized that modern pedagogical science interprets multicultural competence as an integrative personal professional quality of the future specialist, which ensures his/her ability to carry out intercultural interaction in the modern conditions of the globalized space. The author regards the term of the multicultural competence of the future foreign language teachers as a complex integrated concept that reproduces the ability of the individual not only to promote their own cultural heritage, but also to be ready for productive interaction in the context of the multicultural environment on the basis of the dialogue of culture, mutul understanding, mutual respect and tolerant attitude towards the cultural values of other nationalities.

The usage of different interactive methods for the purpose of future foreign language teachers' polycultural competence formation is suggested.

Key words: quality of education, professional training, competence, competence, polycultural competence, competence approach, higher educational establishment, future foreign language teachers. 